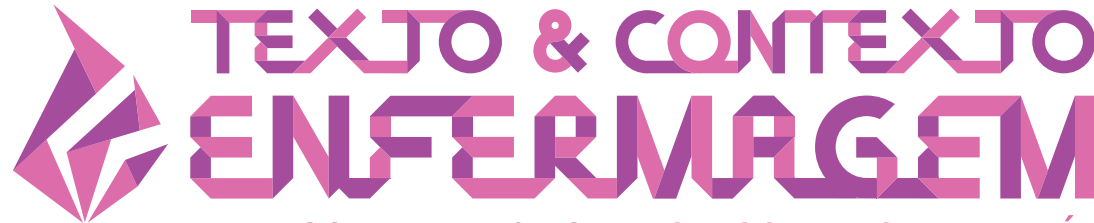

TEXT \& CONTEXT NURSING TEXTO \& CONTEXTO ENFERMERÍA

\section{EXPERIENCE OF FAMILIES FACING CANCER IN PALLIATIVE CARE}

\author{
Cínthia Cristina Oliveski ${ }^{1}$ \\ Nara Marilene Oliveira Girardon-Perlini' ${ }^{1}$ \\ Silvana Bastos Cogo $^{1}$ \\ Franciele Roberta Cordeiro 2 (1) \\ Fernanda Cristóvão Martins ${ }^{3}$ (1) \\ Priscila Perfeito $\mathrm{Paz}^{3}$ (1)
}

${ }^{1}$ Universidade Federal de Santa Maria, Programa de Pós-graduação em Enfermagem. Santa Maria, RS, Brasil. 2Universidade Federal de Pelotas, Programa de Pós-graduação em Enfermagem. Pelotas, RS, Brasil. ${ }^{3}$ Universidade Federal de Santa Maria, Curso de Graduação em Enfermagem. Santa Maria, RS, Brasil.

\begin{abstract}
Objective: to understand the experience of families facing cancer in palliative care of one of its members. Method: this is a qualitative research based on the theoretical-methodological framework of Grounded Theory. Six families participated, totaling 15 people. Data were collected from January to December 2019 in the homes of families in a municipality in southern Brazil, through an in-depth interview with the construction of a genogram. Analysis followed the constant comparative method steps: open, selective and theoretical coding. Results: the concepts discovering cancer; suffering with the reality imposed by the illness; preparing to face illness; deciding on treatment; facing the finitude of life, they are part of the central category "Living one day at a time", which symbolically defines families' experiences. The substantive theory elaborated shows that the definitions, actions and strategies adopted by families, in family dynamics and in interpersonal interactions, along a trajectory that culminates in the terminality of a relative's life, is permeated by hope maintenance.

Conclusion: throughout the illness experience, families promote changes in their daily lives and in family dynamics, undergoing adaptations and using their internal strengths in an attempt to re-establish the balance prior to the disease. Families live with uncertainty about the future, but it is the hope that drives them to live one day at a time.
\end{abstract}

DESCRIPTORS: Family. Hospice care. Neoplasm. Nursing. Grounded theory. 


\section{EXPERIÊNCIA DE FAMÍLIAS FRENTE AO ADOECIMENTO POR CÂNCER EM CUIDADOS PALIATIVOS}

\section{RESUMO}

Objetivo: compreender a experiência de famílias frente ao adoecimento por câncer em cuidados paliativos de um de seus membros.

Método: pesquisa qualitativa pautada no referencial teórico-metodológico da Teoria Fundamentada nos Dados. Participaram seis famílias, totalizando 15 pessoas. Os dados foram coletados, de janeiro a dezembro de 2019, nas residências das famílias, em um município no Sul do Brasil, por meio de entrevista em profundidade com a construção do genograma. A análise seguiu os passos do método comparativo constante: codificação aberta, seletiva e teórica.

Resultados: os conceitos descobrindo o câncer; sofrendo com a realidade imposta pelo adoecimento; preparando-se para enfrentar o adoecimento; decidindo a respeito do tratamento; deparando-se com a finitude da vida integram a categoria central Vivendo um dia de cada vez, que define simbolicamente a experiência da família. A teoria substantiva elaborada evidencia que as definições, ações e estratégias adotadas pela família, na dinâmica familiar e nas interações interpessoais, no decorrer de uma trajetória que culmina na terminalidade da vida de um familiar, é permeada pela manutenção da esperança.

Conclusão: ao longo da experiência de adoecimento, as famílias promovem mudanças no cotidiano e na dinâmica familiar, passando por adaptações e utilizando suas forças internas na tentativa de reestabelecer o equilíbrio prévio à doença. As famílias convivem com incertezas quanto ao futuro, mas é a esperança que as impulsiona a viver um dia de cada vez.

DESCRITORES: Família. Cuidados paliativos na terminalidade da vida. Neoplasias. Enfermagem. Teoria fundamentada.

\section{EXPERIENCIA DE LAS FAMILIAS QUE ENFRENTAN LA ENFERMEDAD DEL CÁNCER EN CUIDADOS PALIATIVOS}

\section{RESUMEN}

Objetivo: comprender la experiencia de las familias que enfrentan la enfermedad oncológica en los cuidados paliativos de uno de sus miembros.

Método: investigación cualitativa, basada en el marco teórico-metodológico de la Teoría Fundamentada. Participaron seis familias, totalizando 15 personas. Los datos fueron recolectados de enero a diciembre de 2019 en los hogares de las familias en un municipio del sur de Brasil, a través de una entrevista en profundidad con la construcción del genograma. El análisis siguió los pasos del método comparativo constante: codificación abierta, selectiva y teórica.

Resultados: los conceptos que descubren el cáncer; sufrir con la realidad impuesta por la enfermedad; prepararse para enfrentar la enfermedad; decidir el tratamiento; afrontar la finitud de la vida forman parte de la categoría central "Vivir un día a la vez", que define simbólicamente la experiencia de la familia. La teoría sustantiva elaborada muestra que las definiciones, acciones y estrategias adoptadas por la familia, en la dinámica familiar y en las interacciones interpersonales, a lo largo de una trayectoria que culmina en la terminalidad de la vida de un familiar, está permeada por el mantenimiento de la esperanza.

Conclusión: a lo largo de la vivencia de la enfermedad, las familias promueven cambios en su vida diaria y en la dinámica familiar, experimentando adaptaciones y utilizando sus fortalezas internas en un intento por restablecer el equilibrio previo a la enfermedad. Las familias viven con incertidumbre sobre el futuro, pero es la esperanza la que las impulsa a vivir un día a la vez.

DESCRIPTORES: Familia. Cuidados paliativos al final de la vida. Neoplasia. Enfermería. Teoría fundamentada. 


\section{INTRODUCTION}

Cancer is a chronic disease that affects the life of a person who experiences it and their family, as there is not a separate subject and disease, but individuals who fall ill along with their family. From this perspective, family is conceived as "a group that identifies itself as such, composed of people who, united by biological, affective or affinity bonds, have a sense of belonging, commit to each other and share values, beliefs, knowledge and practices"1:361.

From diagnosis of cancer, the path of an uncertain, painful and prolonged treatment for patients begins, which often weakens families and future plans. Illness causes destabilization of family dynamics and suffering to its members, since families affects individuals' health, and individuals' health affects families $^{2-3}$.

Even with technological development, there is still an expressive number of people with cancer who, despite the efforts for treatment, reach incurability. In these situations, in which the disease progresses and it no longer responds to the treatment that intends to change it, death is directed, despite the temporal course ${ }^{4}$. At the end of life, palliative care works to provide means that promote or maintain dignity and quality of life ${ }^{5}$. This approach aims to prevent and alleviate suffering through early identification of signs and symptoms, adequate assessment and treatment of physical, psychosocial and spiritual problems ${ }^{6}$. With this, it provides conditions that improve the well-being and comfort of patients and families facing life-threatening diseases such as cancer.

Given the terminality, families suffer together with the sick person and, in view of changes in the health of one of its members, all the other members are affected, configuring it as essential that it be included in the care process, as a significant part of cultural, personal and subjective contexts ${ }^{3,7}$. In this sense, evidence indicates that situations of illness due to neoplasms alter family dynamics and tend to be enhanced when the available treatments do not have a therapeutic effect ${ }^{8,9}$, triggering ambivalent feelings related to loss, fear of seeing relatives' suffering and decay, impotence, guilt, and attempt to repair ${ }^{9,10}$. Care demands can pose a challenge to families, family burden and financial expenses ${ }^{11}$. Moreover, at the end of life, families need to be close to patients, feel useful and find meaning for patients' illness and death ${ }^{12}$.

In the literature ${ }^{8-12}$, studies indicate the importance of understanding how the meanings present in family interaction mobilize the actions of families in the face of cancer that does not respond to the modifier treatment, enabling the broadening of knowledge related to family life. In this context, nursing team's work is essential to provide comfort to patients and their families, helping them to experience the process of dying with dignity, and to use, in the best possible way, the time they have left. That is, to help the human being to seek quality in the days lived, when it is no longer possible to add quantity ${ }^{4}$. To do so, it is necessary to approach that experienced by families.

Based on the above, this study has as research question: How do families experience cancer in palliative care by one of their members? This study aimed to understand the experience of families facing cancer in palliative care of one of its members. 


\section{METHOD}

This is a qualitative research, supported by the Grounded Theory (GT) framework and presented according to the COnsolidated criteria for REporting Qualitative research (COREQ) checklist. GT is characterized as a method of investigation that proposes to develop theoretical explanations for events of human experience, allows to understand the meanings of social actors' actions, investigate interactions, behaviors, perceptions and their thinking in relation to a given social object. From systematic and comparative analysis of data, it makes it possible to generate theories based on the central category and related concepts ${ }^{13}$.

As reference places for gathering the families, the Home Care Service and the Matrix Team of Palliative Care Consulting linked to a large university hospital, located in southern Brazil, were selected. These services provide assistance to patients and families diagnosed with irreversible advanced disease who need follow-up during hospitalizations and/or at home and indicated those who were in cancer care.

The participants were six families, totaling 15 people, who had one of their members with cancer out of the possibility of cure. This number was defined by theoretical sampling and with the achievement of theoretical saturation, i.e., when no new dimensions or relationships emerged during the analysis that contributed to understanding the categories and formulating the theory ${ }^{13}$. In the research, the family unit was represented by the participation of at least two members, and it was established that one of these could be sick relatives and at least one person following them in the process of illness. The choice of which people would participate in the interview was a family decision.

Families who lived with a family member diagnosed with cancer who did not respond to the modifier treatment, regardless of the type and location of the tumor and who were aware of diagnosis and prognosis were included. Patients with knowledge of their diagnosis, which was confirmed with the healthcare team providing assistance and/or family members prior to the approach were included. Families of children and/or adolescents, people who presented limitations and/or cognitive deficits that prevented them from understanding or answering the interview questions were excluded. For patients, the presence of clinical alterations such as pain, nausea, vomiting or dyspnea was also considered.

The participants were organized into two sample groups. The first sample group consisted of three families who experienced cancer without response to the modifier treatment in a chronological period above two years from diagnosis. The second sample group consisted of three families living with this reality in a period of less than six months. This decision came from the hypotheses generated in the analysis process, in which it was observed that the first families, because they experienced a prolonged illness process, which had lasted for years, appeared to adapt and balance in relation to the changes in roles and family adjustments that were necessary in the initial phase, when diagnosis of incurability was made. Thus, questions were raised regarding how families recently informed of impossibility of cure would manage the situation.

Data were collected in families' homes from January to December 2019. The initial contact was mediated by the hospital service teams that attended patients/families. The professionals explained about the study, the invitation to participate was formulated and the day of the home visit was agreed. At the first moment of the interview, families were invited to build a genogram as an initial strategy of approximation with families and also to facilitate knowledge and visualize the structure and family ties. In-depth interview was then based on the question: How is it for you to experience cancer in families? From this, other questions were formulated in order to broaden the understanding of what relatives thought, felt and did during this experience. The interviews, conducted by a single interviewer (the first author), lasted from 43 minutes to 2 hours and 5 minutes. The statements were audiorecorded with the aid of a portable recorder, transcribed in full and later deleted. Data were organized and 
encoded with the support of the software $\mathrm{NVIVO}^{\circledR}$, version 10. Families were identified with the letter $\mathrm{F}$ (family), followed by the number corresponding to the order of the interviews and the indication of the participating relative (patient, daughter, wife...). It is noteworthy that all the guests agreed to participate in the study.

Data were collected and concomitantly analyzed, according to the precepts of GT, through the constant comparative method, composed of three stages: open, selective and theoretical coding ${ }^{13}$. In the analysis process, the memos and diagrams elaborated helped formulate the theory and describe it. In the theoretical coding stage, the coding of the six Cs was elected using: context, which expresses the circumstances in which the experience occurred, integrating it and permeating it in the whole; intervening condition, which represents data classification so that it presents itself in this way; contingency, which expresses situations that may or may not happen, but when they happen, modify and interfere in the way the experience is experienced; and consequence, which includes results, effects, efforts, functions, predictions, and consequences ${ }^{14}$.

From the analysis process, the following concepts were organized: Discovering cancer, which presents families' life context. The strategies and actions undertaken by families during the experience are explained in the concepts Suffering from the reality imposed by illness and preparing to face illness. The concept of Deciding on treatment expresses the paths taken by families during illness, with regard to the choice of therapeutic options, which modify the way the experience is experienced. And finally, coming across the finitude of life, which illustrates the consequence of illness from cancer without cure in families' lives. These interrelated and articulated concepts support the central category "Living one day at a time", which allows us to understand the experience of families facing cancer in palliative care.

The research was approved by the Research Ethics Committee and the ethical principles that regulate research involving the participation of human beings were followed during all study stages. All participants signed the Informed Consent Form (ICF) in two copies.

\section{RESULTS}

Among the six families interviewed, 15 people were attended, including six patients, three spouses, three daughters, a mother, a sister and a friend. The age of the sick people ranged from 41 to 79 years, with an average of 57 years, and the time of diagnosis of cancer without cure was from 3 months to 3 years. The relatives were between 19 and 75 years old, with an average of 46 years.

Concept analysis and how they interrelate with each other and with the subconcepts made it possible to identify the central category "Living one day at a time", which resulted in the construction of substantive theory "Allowing themselves to maintain hope: the experience of families facing cancer in palliative care". In the theory's representative diagram (Figure 1), the concepts and subconcepts that, interrelated, show the movement that families perform, in family dynamics and in interpersonal interactions, since the discovery of cancer, the repercussions that discovery triggers on families, the strategies used to face illness and treatment, which culminate in the terminality of patients' lives. 


\section{Allowing to keep hoperul}

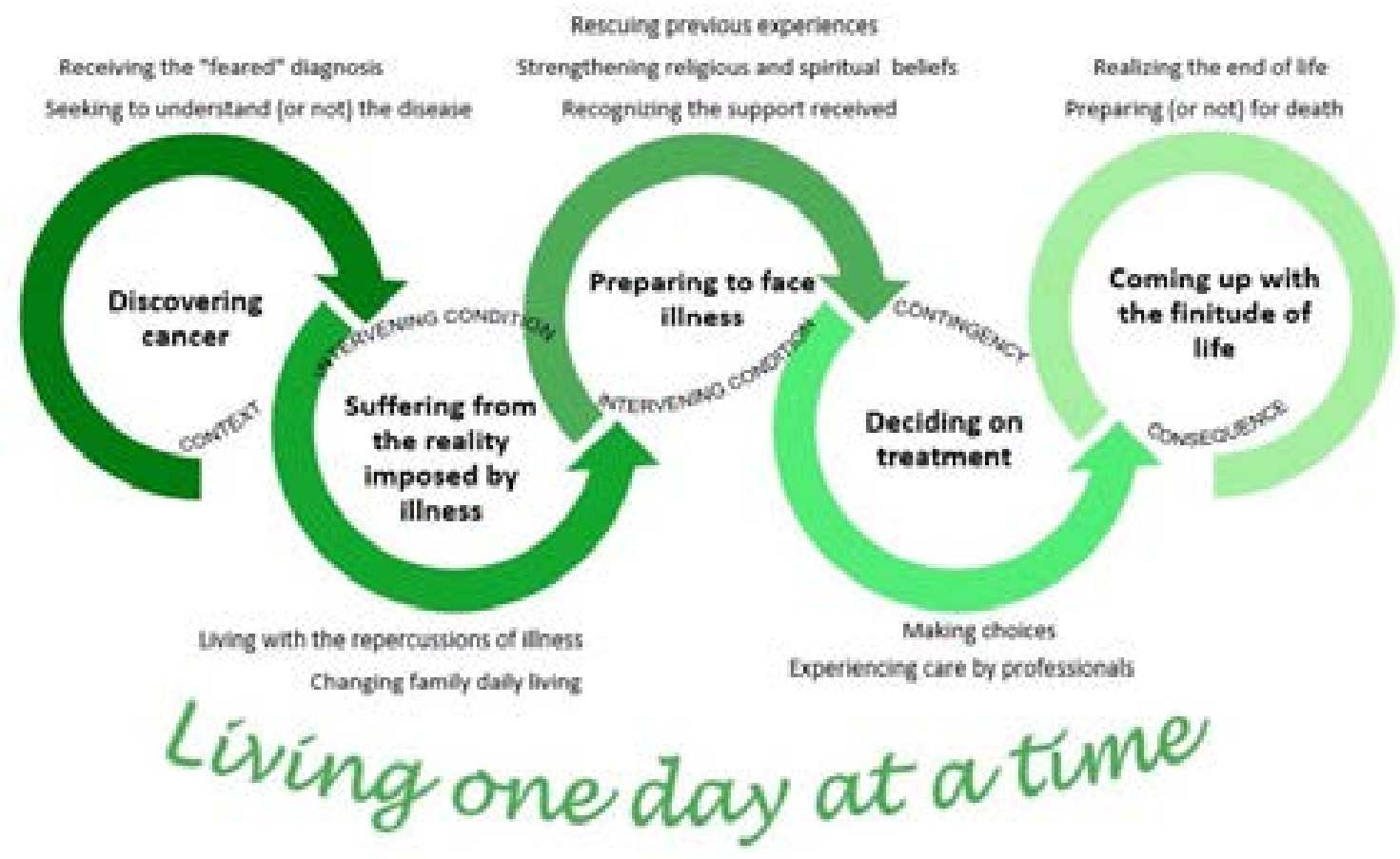

Figure 1 - Representative diagram of substantive theory: Allowing themselves to maintain hope: the experience of families facing cancer in care palliative.

"Living one day at a time" represents the actions and strategies that families use to face cancer in palliative care by one of its members. Aware that the finitude of life approaches, families does not project the distant future, but allows itself to maintain hope, living one day at a time, from disease diagnosis to the proximity of death. It sustains families during the days, weeks or months of suffering, taking on various forms, i.e., each family resignifies hope, according to the possibilities that open up. In many cases, the cure of the disease is not projected, in view of near death, however, families nourish hope by living one day at a time.

"Discovering cancer" represents the context where the experience occurs. This permeates receiving a diagnosis, which is feared and leads to the search for understanding (or not) the disease. When observing physical alterations, families have the first contact with the clinical manifestations of illness, defining actions that allow leading to a diagnosis. By performing various tests and going through health services, families cultivate the hope that this is not a serious disease. However, when they receive confirmation of cancer, families feel the initial impact of diagnosis of a chronic disease. The symptoms previously presented now have definition of their cause and refer to the meaning of an unexpected pathology. Families already anticipates the trajectory that is beginning and, with this, feelings of sadness, anguish and fear emerge as soon as cancer diagnosis is revealed. [...] The day I knew what Mom had, I felt like making a hole and burying myself in the ground so desperate. (F6 - daughter). 
Families feel impacted, however, they use their internal forces to try to understand illness and assume what is to come, as a strategy to assist in coping. Some families presume causes for the occurrence of cancer, which expresses that the act of reflecting and questioning the reason for being affected by the disease can be therapeutic, in the sense that dialogue and exchanges between relatives help in the interpretation of reality and bring them closer to the decisions that will be necessary. The supposed causes listed by families are not restricted to issues of genetic, hereditary or life habitsnature, but also the personality characteristics that are referred to as a cause-effect for the onset of cancer. [...] Pancreatic cancer is rare, it's a cancer you're looking for[...] for sedentary lifestyle, for not taking good care of food, for working too hard. The sorrows that we keep favors to have this type of cancer. I was a person rich in hate. (F5 - sick relative).

In addition to inferring causes for cancer, families act considering the possibility of knowing more about the disease and the negative in knowing.[...] I tried to know more about cancer and it was good because I had an understanding of what the disease was like and what the (F1 - sick relative) would look like. [...] I said: we will not even seek to know more about it, we will not research anything! Because if we know what can happen, it seems that it is waiting (F2 - daughter). By channeling their forces in an attempt to better understand the disease, families try to identify the possible path that will be trodden, both in terms of treatment and in clinical evolution of the disease. However, by avoiding knowing more about the disease, it may demonstrate difficulty in dealing with the reality that presents itself and with the outcomes that may acome.

Suffering from the reality imposed by illness is an intervening condition that determines how families feels the impacts and how it will generate strategies that help adapt to reality. In addition to this impact, there is the recognition of disease severity, evidenced by the physical complications that become increasingly severe and limiting. Families realize that life will no longer be as before, being confronted with fears, worries and anxiety when they glimpse what might happen.

The perception of limited daily life is frequent, since patients will not perform the activities they they used to or present severe limitations. Autonomy becomes compromised, and the simple functions of daily and leisure routine, such as shopping or performing the activities of organization and cleaning of the house, are compromised. The disease imposes limits on patients, and affects the other limbs, because they need to adjust to minimize the restrictions evidenced. [...] The father had to learn how to make food for his mother. He, who had never made a pot of food, now cooks. Before, it was the mother who did everything until she paid the bills. So, we need to reorganize ourselves into all activities (F3 - daughter).

The need to break labor ties indicates one of the changes that most impact families. In this study, two possibilities were glimpsed: the request for dismissal by the relative who will become a caregiver; and disability retirement for patients. [...] I asked you to quit my job when we discovered cancer. I even tried to work a little longer, but it didn't work. So, I didn't think twice! I will always give priority to the person I love, rather than the job. She's in need of me and I have my whole life to work. (F5 - husband). [...] I was a caregiver of an elderly person, but I left when I got sick. I had to retire because I couldn't work anymore. I was retired for disability (F3 - sick relative).

It was also identified the removal of some relatives, which shows that any change in a relative, such as illness, will affect, in some way, everyone. The unpredictability that involves cancer exposes families to emotional distress and tension, which can cause disagreements among people. For many families, this condition acts as a force for rapprochement and strengthening of family bonds, however, others experience weaknesses in family cohesion, which can lead to relationship rupture and distancing among its members. 
Preparing to face illness reveals family actions and thought strategies that enable caring for the sick relative to continue. Families is sensitized to help seek attitudes that can encourage patients, and to recall previous successful situations and strengthen religious and spiritual beliefs are actions committed in this attempt. [...] He's even had hepatitis and taken it out of his hand! (F4 - sister). This internal tool is predominant to encourage and strengthen family bonds, as if it were a reminder that they have been through worse or similar situations, but "survived".

On the other hand, negative situations can be assumed as limiting beliefs regarding the influence of the problem on families, as they increase family suffering and decrease problem-solving options, since they have the ability to inhibit initiatives and decision-making.

Many families find resources to face illness by strengthening religious and spiritual beliefs. Spirituality is manifested by optimistic and persevering behaviors that, even in the face of adversity, drive families to maintain hope. By recognizing the support received, the families demonstrate that the presence and support of relatives, especially those with whom they bond during this period, become indispensable to alleviate the difficulties experienced.

Deciding on the treatment relates to the paths that can be trodden by families, with regard to treatment options. Thus, families strive to respect the autonomy related to patients's decision-making power regarding their therapeutic choices. [...] The doctor suggested I do two chemo to try, it was a try. Then I talked to my daughters, we all decide together. Then they said, Mom, try two! Let's try! (F6 - sick relative). Although families recognize the limitations of curative therapeutic resources, the joint decision on treatment refers to the idealization and hope of cure, even if it is not possible.

When they experience the palliative care approach, families develop definitions of their understandings related to this care. Thus, it was evidenced that, in some cases, families were unaware of objectives in palliative care (PC), but when experiencing them, they can identify improvement in care, in addition to receiving increased attention to their demands. The understanding of what constitutes PC is difficult for families, although professionals strive to spread the precepts that they should start in the presence of any life-threatening diseases, and not only in the presence of cancer or at the end of life. Thus, PC is perceived as a necessary condition to maintain life, with regard to biological aspects, in the promotion of comfort and quality of life. [...] Palliative care is one that will not solve the disease, it is to keep as much as you can, without pain... keep as much comfort as possible, for me to have a life (F4 - sick relative).

The care provided by the interdisciplinary team was referred to by the families as a positive experience, without, however, a specific reference to the role of nursing regarding this aspect. In the context in which families were living, suffering and uncertainties, the relationships of trust and the bond constituted with the professionals strengthen them and provide security. The families identified, in the presence and care received by the nursing team, attitudes that denote attention, when professionals are willing to welcome them in their insecurity and fears, providing relevant information and willing to stay together, when the families wish. This form of interpersonal relationship, based on the genuine interest in patients' comfort and well-being, also provides security to families.

However, there were times when families felt careless by the health team, especially when professionals made discouraging projections, configuring them as non-effective actions to cope with the disease. [...] The doctor gave me a sentence of three months to live and I experienced a trauma because I didn't know what day I was going to die. It was very sad (F3 - sick relative).

It is evident that the families expect the health team to exercise empathy and compassion, especially with regard to the establishment of an effective communicative process that meets their expectations. The lack of empathy is felt as disregard for families, its values, its belief system, its desires and its afflictions. Therefore, compassion is expected in the sense that professionals do not have indifference to the suffering of those under their care. 
Facing the finitude of life is the consequence of families' experience with cancer without possibilities of modifier treatment. The perception that end of life is approaching is difficult to cope with, because it is necessary to abandon the expectation of a future in which patients is present and, yes, to deal with the concrete situation of death. It indicates that families resignifies the projections of the future for the present moment. Small doses of hope are sufficient for patients to recover or maintain the desire to stay alive until the day of their death, i.e., staying connected to life until the definitive moment of leaving it. At this moment, both the person and the relatives suffer from worries and fear when they show signs of worsening health and when they make projections for when this happens. [...] I worry that he will look bad when I am alone with him at home (F4 - wife).

Cancer that no longer responds to modifier treatment results in a prolonged period of illness, and most of the time, the uncertain future becomes one of the main family concerns. Thoughts of what disease progression will be like, exacerbation of symptoms and death cohabit families' imagination. With the proximity to death, families feel powerless when they cannot relieve relatives' suffering as well as because they do not have the means to contain the progression of cancer, which will trigger end of life. The feeling of helplessness can incite in families the attempt to remain strong in the face of adversities that arise. Families seeks encouragement of strength and courage, the will to fight and the commitment not to give up. [...] We have to have strength. You have to draw strength from the bottom. We cling to everything that is thing (F6 - sick relative).

Cancer in PC favors families to give up resources to resist the period of tension. The attempt to remain strong demonstrates the search for a balance between change and stability, permeated by family resilience. This movement, in addition to strengthening cohesion among the members, acts as a motivation for patients to believe in their recovery. Families recognizes the elements that corroborate patients's frailty, however, they continue to maintain confidence that there is a possibility of improvement. [...] While there is life, there is hope! (F3 - spouse).

When patients are not recovered, families begin to consider death as inevitable and establishes its line of action, organizing what it considers necessary, for when this moment arrives. In this sense, the plans for the future are adjusted, since the demands related to end of life are prioritized and become part of families' routine. It is noteworthy that many plans need to be adequate to the context of the disease to be maintained, requiring members to mobilize to maintain them.

For this, they promote the resolution of pending issues, which is when families stand before the possibilities that may happen. Patients is impelled to make decisions, to organize matters that, if unresolved, can cause burden to families when they are no longer present. The concern to deliberate on banking issues, socialize passwords and carry out legal procedures to ensure access to finances and the right to pension, in addition to debt discharge, were measures adopted.

With the perception that death is approaching, sick persons begin to evaluate their legacy and project themselves to the future through the memories of those who will remain alive. Thus, reconciliation actions are also carried out, aiming not to leave or mitigate pending issues in the affective and social sphere. Families seeks, through small care in daily life, to meet sick relatives' wishes, as a way to manifest zeal, interest, appreciation and willingness to grant some kind of pleasure and satisfaction. The interest in the well-being of the other proves to be what really matters to families.

It was found that families often avoid thinking about death and avoids talking about it, either among its members or with the health team. This behavior may be due to pain and suffering when recalled the situation experienced by patients. The option of not thinking about what can happen expresses a limiting family belief, which prevents us from sharing fears and strengthening in the collective, in the expectation that not speaking can ward off suffering and postpone death. [...] We hardly talk about it [death]. Bad thing is not spoken. If we can't forget, why should we be talking? So, we do not realize that we have no disease (F2 - daughter). 
However, other families accept the prospect of death as a concrete event that can happen. By admitting that death is inevitable and over which one has no control, families talk about terminality, among its members and with professionals. [...] Talking we understand each other and try to take care of what may happen. It's like I usually say: with your mouth shut you don't talk. So we talk a lot, talk about the now and the after. We've talked about everything! (F5 - husband).

It is identified that, although there is no full resignation, there is no more resistance to understand and accept their destiny. Gradually, families begin to see that death approaches and thus develops resources to deal with this perspective. As families reflects on end of life, families find strength to continue to face this moment.

\section{DISCUSSION}

The substantive theory elaborated allows us to understand that the experience of families in the face of cancer in PC by one of its members refers to the trajectory of illness, whose actions undertaken and the decisions taken, after knowing disease incurability, are driven by the purpose of living one day at a time. This purpose is part of internal decision-making experienced by families that mobilizes them to allow themselves to maintain hope, even in the face of the perspective of death. Hope fosters family cohesion, strengthens difficulties and acts as a source of incentive to face the suffering and pains of the present and the future.

In cancer in PC, families' comprehensiveness is threatened, since each member is personally affected by the diagnosis and its consequences, especially by the advanced stage of death ${ }^{4}$. In the face of an adverse situation, individuals and their family perceive the repercussions on the family unit, on the disorganization of each person's life and on the demands that need to be met $^{2}$.

This situation imposes on relatives changes in their roles in the family group ${ }^{15}$. Families needs to reorganize, considering that their functions need to be rethought and distributed, in order to mitigate the negative repercussions and develop skills to meet a sick person's needs ${ }^{16-17}$. This is a complex and challenging experience because families will need to review planned decisions ${ }^{18}$.

Illness generates changes in family dynamics, unbalancing it. The changes initiated in the pre-diagnosis period, i.e., at the beginning of symptoms, permeate the entire stages of the disease, and may continue after the death of a patient. However, families strive to restore stability, which can foster still unknown capabilities regarding the ability to solve crises and readapt.

The way of coping with illness and the perspective of death is shaped by families's belief system, which, in turn, is formatted by the experiences experienced so far and by those transmitted transgenerationally. Families, together with patients, suffers in the stages of diagnosis, treatment and other stages that permeate the disease ${ }^{19}$. Thus, it can exacerbate feelings and attitudes of sadness, hope, fear, insecurity, confusion, apathy, despair, overprotection, tranquility, among others.

In this context, families try to live "normally", one day at a time, even in the face of adverse situations present. This movement of "normality" is understood as families's desire to adjust to the new reality that the disease brings and live life, as close as possible, to the one lived before the disease ${ }^{18}$. From this perspective, normality allows families to use illness to resignify life and hope while they are aware of proximity of death. In the process of caring, despite the sadness they experience, they choose to be at the side of the relative, turning this experience into something significant ${ }^{20}$. Living with cancer without a cure can be an opportunity for patients and family to find meaning in their lives. 
From this perspective, developing resilience is important for patients and their families ${ }^{21}$. Resilience refers to the ability to resist and recover from disturbing vital challenges and involves the potential for personal and relational transformation and growth, forged from adversity ${ }^{22}$, and can serve as an impulse for families to deal with the possibility of death, assuming it as an integral part of life ${ }^{23}$. In this context, the results of this study show that families appropriate hope as a source of encouragement and comfort to live the present and project the future.

As the feeling of hope tends to persist at all stages of the disease, patients and families may experience the hope of healing or prolongation of life, of good quality of life, or of a mild and peaceful death ${ }^{18,24}$. In summary, living holds hope, regardless of the meaning it has for families. Hope is redefined as the cancer progresses, i.e., the desire for improvement can become the desire, for example, to complete unfinished tasks ${ }^{25}$.

Thus, hope is dynamic, taking on several facets for each family. The stage of cancer does not influence the degree of hope, i.e., having knowledge of limited prognosis does not negatively change hope. Near end of life, hope is maintained by families and passed on as a legacy of courage for future generations ${ }^{25}$. Patients and their familis begin to focus on the life they are living, rather than projecting death, assuming that "the future is now." ${ }^{26-27}$ Thus, it is understood that, when there is awareness of death, the feeling that there is no time to lose involves families and encourages them to focus on what they consider important, making efforts to maximize time shared with the sick relative, full of pleasant moments.

In the case of patients, a study found that they express a desire to obtain a sense of conclusion in their lives. Having the possibility to make a review of what has been lived, say goodbye to significant people and solve unfinished issues offer them and their family opportunities for better experiencing end of life ${ }^{20}$. The approach to death leads families to reflect on life itself, its existence, and its future ${ }^{23}$.

However, coping with illness and end of life is unique for each family and expresses personal, cultural, social and philosophical beliefs that influence conscious or non-life behaviors ${ }^{28}$. This perspective is evidenced by families's preference to talk or not about terminality, since, for cultural reasons, death remains taboo and to talk openly about it depends on effort and commitment. Communication, when it involves the terminality of life, is complex, either because of the difficulty of expressing oneself, because it occurs in a non-assertive manner or when they do not talk, and can create anguish and frustration. However, regardless of decision, patients and family need to feel supported and united ${ }^{29}$.

In this context, the nursing team emerges with patients with cancer in PC and their families. Nursing is recognized by families for its ability to transmit security in technical and emotional aspects, through presence, listening and understanding. The humanization of care in knowing how to speak and listen, and enabling dialogue in order to understand the breadth of human relations and, then, generating well-being is a differential that provides confidence to patients and relatives ${ }^{30}$. These elements demonstrate the importance of nursing in helping families and the person living the final process of life.

Caring for patients with cancer in PC and their families is complex and requires effort and dedication, especially when there is no response to the modifier treatment. Understanding how families deal with this experience is essential so that professionals can help with the difficulties and needs that surround them. The substantive theory, in seeking to explain the experience of families, seizes that, when they experience care to a relative diagnosed with cancer without a cure perspective, allow themselves to maintain hope, living one day at a time. Hope, therefore, is linked to the interaction between relatives in the present, rather than future events. Families nurture hope in today, not tomorrow. Thus, the incube professionals appropriate this knowledge to qualify the care provided, considering what, in the present, does and gives meaning to families's life. 
The results show the limitation of having included families in care in a single hospital institution. In this sense, conducting research with families in different contexts of health services can contribute to broaden the understanding of this phenomenon. Still, new studies, using GT, can be developed in order to apprehend the experience of families when experiencing grief, considering that nursing care does not end with patients's death, but includes care and support for those who remain.

\section{CONCLUSION}

The impact of cancer on PC promotes changes in daily life and family dynamics, since families undergoes adaptations and uses its internal forces in an attempt to reestablish the balance prior to the disease. Since diagnosis discovery, families have lived with uncertainties about the future, but it is the hope that drives them to live one day at a time.

The way families act is influenced by their beliefs and values, in a singular and dynamic way. The proximity of death did not uneascertain the ability to maintain hope alive, from pleasant days without debilitating or disabling symptoms or from simple joys provided by family coexistence and cohesion. Being out of the possibility of a cure does not mean being out of the possibility of life, as this concept mobilizes families in the expectation that patients will be able to live the life they still have.

IIIness affects family nucleus, since families is interlocutor and participates in this process of vulnerability, because due to the initial impact of the disease, it has the potential to become a source of support for the sick relative, along with the individual resources of each member to cope with cancer. Furthermore, families play important roles in this context: provider of care to patients and recipient of care from the health teams. Therefore, the look at families' experiences is necessary, because understanding the way families moves along this trajectory has implications in the care that will be offered.

The results and the substantive theory outlined here contribute to a gap evidenced in the nursing literature, which refers to family care. Thus, the study broadens the knowledge and understanding about cancer in $\mathrm{PC}$ from the perspective of families. The expectation is that it can contribute to sensitize professionals about the care of this population group, considering the particularities and meanings of actions undertaken by the family unit. 


\section{REFERENCES}

1. Girardon-Perlini NMO, Hoffmann JM, Begnini D, Mistura C, Stamm B. A família frente ao adoecimento por câncer de mama. Rev Enf UFSM [Internet]. 2016 [cited 2020 Dec 07];6(3):36070. Available from: https://doi.org/10.5902/2179769220893

2. Girardon-Perlini NMO, Angelo M. The experience of rural families in the face of cancer. Rev Bras Enferm [Internet]. 2017 [cited 2020 Dec 07];70(3):557-84. Available from: https://doi. org/10.1590/0034-7167-2016-0367

3. Maia FES, Maia FES. A família frente aos aspectos do câncer. Rev Aten Saúde [Internet]. 2016 [cited 2020 Dec 07];14(50):63-9. Available from: https://doi.org/10.13037/ras.vol14n50.3801

4. Tomaszewski AS, Oliveira SG, Arrieira ICO, Cardoso DH, Sartor SF. Demonstrations and necessities on the death and dying process: perspective of the person with cancer. Rev Fun Care Online [Internet]. 2017 [cited 2020 Dec 07];9(3):705-16. Available from: https://doi.org/10.9789/21755361.2017.v9i3.705-716

5. Oliveira MBP, Souza NR, Bushatsky M, Dâmaso BFR, Bezerra DM, Brito JA. Atendimento domiciliar oncológico: percepção de familiares/cuidadores sobre cuidados paliativos. Esc Anna Nery [Internet]. 2017 [cited 2020 Dec 07];21(2):e20170030. Available from: https://doi. org/10.5935/1414-8145.20170030

6. WHO. PalliativeCare: Factsheet. Aug 2017 [Internet]. [cited 04 Apr 2018]. Available from: http:// www.who.int/mediacentre/factsheets/fs402/en/

7. Arias-Rojas M, Carreño-Moreno S, Rojas-Reyes J. Uncertainty towards the disease of family caregivers of patients in palliative Care: a scoping review. Aquichan [Internet]. 2020 [cited 2020 Dec 07];20(3):e2034. Available from: https://doi.org/10.5294/aqui.2020.20.3.4

8. Figueiredo T, Silva AP, Silva RMR, Silva JJ, Silva CSO, Alcântara DDF, Souza LPS, Souza AAM. How can I help? Feelings and experiences of the familiar caregiver of cancer patients. ABCS Health Sci [Internet]. 2017 [cited 2020 Dec 07];42(1):34-9. Available from: https://doi. org/10.7322/abcshs.v42i1.947

9. Gomes H, Borges MPM, Baptista G, Galvão AM. A relação de ajuda ao doente em fim de vida e família: o enfermeiro e o cuidar em fim de vida. Revista Studere Ciência \& Desenvolvimento [Internet]. 2017 [cited 2020 Dec 07];1(1):98-120. Available from: http://hdl.handle.net/10198/14562

10. Coelho A, Barbosa A. Family anticipatory grief: an integrative literature review. Am J Hosp Palliat Care [Internet]. 2017 [cited 2020 Dec 07];34(8):774-85. Available from: https://doi. org/10.1177/1049909116647960

11. Barbosa RMM, Ferreira JLP, Melo MCB, Costa JM. A espiritualidade como estratégia de enfrentamento para familiares de pacientes adultos em cuidados paliativos. Rev SBPH [Internet]. 2017 [cited 2020 Dec 07];20(1):165-82. Available from: http://pepsic.bvsalud.org/scielo. php?script=sci_arttext\&pid=S1516-08582017000100010\&Ing=pt

12. Santana JCB, Pessini L, Sá AC. Vivências de profissionais de saúde frente ao cuidado a pacientes terminais. Enfermagem Revista [Internet]. 2017 [cited 2020 Dec 07];20(1):1-12. Available from: http://periodicos.pucminas.br/index.php/enfermagemrevista/article/view/15410

13. Glaser BG, Strauss A. The Discovery of Grounded Theory. Chicago, IL(US): Aldine, 1967. 271 p.

14. Glaser BG. Theoretical sensitivity: advances in the methodology of grounded theory. Mill Valley, CA (US): Sociology Press; 1978.

15. Goldblatt H, Granot M, Zarbiv E. "Death lay here on the sofa": reflections of young adults on their experience as caregivers of parents who died of cancer at home. Qual Health Res [Internet]. 2019 [cited 2020 Dec 07];29(4):533-44. Available from: https://doi.org/10.1177/1049732318800676 
16. Ferraza A, Muniz RM, Pinto BK, Viegas AC, Matos MR. A sobrevivência ao câncer na perspectiva da família. Rev enferm UFPE on line [Internet]. 2016 [cited 2020 Dec 07];10(3):1022-18. Available from: http://doi.org/10.5205/reuol.8702-76273

17. Tarberg AS, Kvangarsnes M, Hole T, Thronæs M, Madssen TS, Landstad BJ. Silent voices: family caregivers' narratives of involvement in palliative care. Nursing Open [Internet]. 2019 [cited 2020 Dec 07];6:1446-54. Available from: https://doi.org/10.1002/nop2.344

18. García-Rueda N, Carvajal Valcárcel A, Saracíbar-Razquin M, Arantzamendi Solabarrieta M. The experience of living with advanced-stage cancer: a thematic synthesis of the literature. Eur J Cancer Care [Internet]. 2016 [cited 2020 Dec 07];25(4):551-69. Available from: https://doi. org/10.1111/ecc.12523

19. Marchi JA, Paula CC, Girardon-Perlini NMO, Sales CA. The meaning of being-a-caregiver of a dependent relative suffering from cancer: palliative contributions. Texto Contexto Enferm [Internet]. 2016 [cited 2021 Mar 26];25(1):e0760014. Available from: https://doi.org/10.1590/010407072016007600014

20. Lima CP, Machado MA. Cuidadores principais ante a experiência da morte: seus sentidos e significados. Psicol Cienc Prof [Internet]. 2018 [cited 2020 Dec 07];38(1):88-101. Available from: https://doi.org/10.1590/1982-3703002642015

21. Sousa-Junior P, Teixeira S. A importância da espiritualidade no tratamento de pacientes oncológicos: uma revisão de literatura. Revista Interdisciplinar de Promoção da Saúde [revista na Internet]. 2019 [cited 2020 Dec 07];2(1):61-9. Available from: https://doi.org/10.17058/rips.v2i1.13195

22. Castro FV, Lourenço L. Resiliência, população e território: contributo conceptual para a terminologia dos riscos. Territorium [Internet]. 2017 [cited 2020 Dec 07];24:5-13. Available from: https://doi. org/10.14195/1647-7723_24_1

23. Prado E, Sales CA, Girardon-Perlini NMO, Matsuda LM, Benedetti GMS, Marcon SS. Vivência de pessoas com câncer em estágio avançado ante a impossibilidade de cura: análise fenomenológica. Esc Anna Nery [Internet]. 2020 [cited 2020 Dec 07]; 24(2):e20190113. Available from: https:// doi.org/10.1590/2177-9465-ean-2019-0113

24. Berri B. A esperança como ajustamento criativo: reflexões dos processos de saúde, doença e morte em gestalt terapia. Rev Abordagem Gestalt [Internet]. 2020 [cited 2020 Dec 07];26(3):35160. Available from: https://doi.org/10.18065/2020v26n3.10

25. Davis MP, Lagman R, Parala A, Patel C, Sanford T, Fielding F, et al. Hope, symptoms, and palliative care: do symptoms influence hope? Am J Hosp Palliat Care [Internet]. 2017 [cited 2020 Dec 07];34(3):223-32. Available from: https://doi.org/10.1177/1049909115627772

26. Cottingham AH, Cripe LD, Rand KL, Frankel RM. "My Future is Now": A qualitative qtudy of persons living with advanced cancer. Am J Hosp Palliat Care [Internet]. 2018 [cited 2020 Dec 07];35(4):640-6. Available from: https://doi.org/10.1177/1049909117734826

27. Arantzamendi M, García-Rueda N, Carvajal A, Robinson CA. People with advanced cancer: the process of living well with awareness of dying. Qual Health Res [Internet]. 2020 [cited 2020 Dec 07];30(8):1143-55. Available from: https://doi.org/10.1177/1049732318816298

28. Lima R, Borsatto AZ, Vaz DC, Pires ACF, Cypriano VP, Ferreira MA. A morte e o processo de morrer: ainda é preciso conversar sobre isso. REME Rev Min Enferm [Internet]. 2017 [cited 2020 Dec 07];21:e-1040. Available from: https://doi.org/10.5935/1415-2762.20170050

29. Pino GK, Murillo HM, Suárez BL. Acompañamiento al enfermo crónico o terminal y calidad de vida en familia. Rev Poiésis. [Internet]. 2019 [cited 2020 Dec 07];36:126-46. Available from: https://doi.org/10.21501/16920945.3194 
30. Prado RT, Leite JL, Silva ÍR, Silva LJ. Communication in the management of the nursing care before the death and dying process. Texto Contexto Enferm [Internet]. 2019 [cited 2021 Jan 27];8:e20170336. Available from: https://doi.org/10.1590/1980-265X-TCE-2017-0336 


\section{NOTES}

\section{ORIGIN OF THE ARTICLE}

Article extracted from the dissertation - Experiência de familias frente ao adoecimento por câncer sem possibilidade de cura, presented to the Graduate Program in Nursing of Universidade Federal de Santa Maria, in 2020.

\section{CONTRIBUTION OF AUTHORITY}

Study design: Oliveski CC, Girardon-Perlini NMO.

Data collection: Oliveski CC.

Data analysis and interpretation: Oliveski CC, Girardon-Perlini NMO.

Discussion of results: Oliveski CC, Girardon-Perlini NMO.

Writing and/or critical review of content: Oliveski CC, Girardon-Perlini NMO, Cogo SB, Martins FC, Paz PP, Cordeiro FF.

Review and final approval of the final version: Oliveski CC, Girardon-Perlini NMO, Cogo SB, Martins FC, Paz PP, Cordeiro FF.

\section{FUNDING INFORMATION}

The research was carried out with the support of the CAPES - Coordenação de Aperfeiçoamento de Pessoal de Nível Superior - Financing Code 001 and the Institutional Scientific Initiation Scholarship Program of the University Hospital of Santa Maria (PROIC-HUSM - Programa Institucional de Bolsas de Iniciação Científica do Hospital Universitário de Santa Maria).

\section{APPROVAL OF ETHICS COMMITTEE IN RESEARCH}

Approved by the Ethics Committee in Research with Human Beings of Universidade Federal de Santa Maria, under Opinion 3.109.307/2019 and CAAE Certificate of Presentation for Ethical Consideration 04885718.5.0000.5346.

\section{CONFLICT OF INTEREST}

There is no conflict of interest.

\section{EDITORS}

Associated Editors: Selma Regina de Andrade, Gisele Cristina Manfrini, Laura Cavalcanti de Farias Brehmer, Ana Izabel Jatobá de Souza.

Editor-in-chief: Roberta Costa.

\section{HISTORICAL}

Received: February 02, 2021.

Approved: April 26, 2021.

\section{CORRESPONDING AUTHOR}

Nara Marilene Girardon-Perlini

nara.girardon@gmail.com 